\title{
RIGHTS AND DUTIES OF OWNERS AND MORTGAGEES
}

\author{
W. T. Craig*
}

An essential step in bringing disaster areas back to normal must be the restoration of full communications and public utilities (1.e. roads, railways, telephones, electricity, etc.). As demonstrated in Inangahua the respective Government departments have the organisation and equipment to get on with these jobs with all speed. But what of the private property owner, be he farmer, shopkeeper or householder, who probably has neither the ability nor the equipment for the job of restoration?

Assistance is forthcoming from many sources almost immediately after a disaster but there can be little organisation of such assistance in the direction of restoration of privately owned property until certain basic information is first obtained. If major work is involved the owner will have to engage a contractor, but first there is the necessity of specifying the work to be done and completing arrangements to finance it. Events have shown that it is not easy to do this quickly. The preparation of specifications for reinstatement of buildings, the obtaining of contractors' quotes and the arrangement of finance take time. In addition a great deal of information must be collected for the benefit of the owner and other Interested parties who require to decide whether restoration is feasible or desirable from an economic or practicable point of view.

Most owners will be insured against earthquake damage to buildings but this does not necessarily solve the financial aspects of restoration, for the insurance proceeds may not be sufficient. Other parties in the shape of mortgagees (who pay half the earthquake insurance premiums) may have a right to claim the proceeds and must be consulted. When property is uninsured the owner carries full financial responsibility but when insurance claims are to be made the problems often come with them. Bxperience has shown that assistance is forthcoming from many sources almost immediately after a disaster but there can be little organisation of such assistance in the direction of restoration of privately owned property until certain basic information is first obtained.

\section{Ownership}

The occupier or apparent owner is not necessarily the true owner. He may hold the land as trustee for an estate, he may be a life tenant or he may have only an equitable interest as a purchaser under Agreement for Sale and Purchase. All permanent buildings on land belong to the landowner but the owner may not be available to provide information and in any event the only conclusive method of finding the true position is to search the land title in the appropriate Land Registry office. 
The Land Registry office holds titles for all freehold land under the Land Transfer system and the old Deeds system, and for registered leases and Mining Residence Site Licences - In fact nearly all the occupied land in New Zealand. Crown leases and Maori leases can also be traced through the respective Government departments.

The starting point for a search is the owner's name or a legal description of the land which will lead to the correct title from the 'Nominal Index' or from the various indices of plans and sections respectively. If neither name nor description is known these can usually be traced through local authority rating rolls or the Govermment Valuation Department.

\section{Encumbrances}

Examination of the title will also disclose any registered mortgages or other encumbrances. As mentioned above mortgagees have certain rights. Generally, insurance over buildings is in name of the mortgagee who has the right to elect whether insurance proceeds are to be applied in repayment or reduction of the mortgage, or towards restoration of the building.

\section{Insurance Cover}

Quite frequently owners are unable to furmish accurate details of insurance covers and often enough they don't even know the insurance company involved. A search for the current renewal certificate may not be possible and information must be sought from local insurance agencies, mortgagees, or perhaps from solicitors who acted in the purchase of the 1and. At Inangahua enquiries were directed through the Earthquake and War Damage Commission to all insurance companies, but confirmation of current insurances was not easy to obtain.

Where property is under-insured or. where the "Indemnity" provisions of the Act are invoked, It may be necessary to fix the value of the property at the time of the occurrence. The Government Roll valuation is a guide, and this figure is obtainable from the valuation Department. It is also shown on the rating roll of the local authority.

\section{Household effects and other chattels}

Insured chattels (e.g. furntture, clothing, personal offects, motor vehicles, etc.) are also covered by earthquake and war damage insurance. The main difference from real property is the lack of registered ownership. The old adage that possession is 9 points of the law applies so far as chattels are concerned but the chattels may, nevertheless, be held under a hire purchase agreement or be secured under an Instrument by Way of Security or similar document. Hire purchase agreements for motor vehicles, farm machinery and most household appliances are "customary agreements" and are not registrable; but Instruments by Way of Security and other chattels securities are registered in one of the Supreme Court Offices in the Provincial District in which the chattels are normally situated. Generally the interests of the hirers or security holders are noted on the insurance policies and they will be entitled to insurance proceeds。

One of the lessons to be learned from Inangahua seems to be that in many respects full knowledge of all relevant factors is a pre-requisite to restoring private properties and settling insurance claims. The task faced by the various Govermment Departments, the Earthquake and War Damage 
Commission and its assessors, local Welfare and Coordinating Committees and others involved in dealing with the problems of the inhabitants, presented many difficulties and problemso Urgency was essential but occasionally they were hampered, not to any great extent but at least inconveniently, by lack of full information in some of the matters referred to above. These difficulties took time to surmount but to the harrassed inhabitants they sometimes seemed too trivial to be a justifiable reason for delay.

Any means which can help to demonstrate to the inhabitants that no effort is being spared should be adopted. Although much of the information might prove redundant, the writer feels that in any future calamity a useful purpose could be served by collecting at a central point, as soon as possible, full details of all affected properties for the use of all those taking part in the work of restoration and reinstatement. Many Government departments and insurance companies are in the process of computerising their records and accounting systems, and these could possibly be programmed to be capable of providing "instant" information on landowners, encumbrances, insurance etc. in any area which had the misfortune to become a disaster area. 